\title{
IMPLEMENTASI METODE PROFETIK PADA PELAJARAN TEMATIK DI KELAS II SDIT SEKOLAH UNGGULAN ISLAMI (SUIS)
}

\author{
Muhammad Nasir, Abdul Hayyi Al-Kattani, Anung Al-Hamat \\ Mahasiswa Pascasarjana Ibn Khaldun UIKA Bogor \\ Muhammad.Nasir1293@gmail.com
}

\begin{abstract}
The awareness of general education teachers who teach "thematic" general subjects is just the transfer of knowledge, without thinking about how to increase faith and also maintain the nature of students from teaching materials that can damage the nature of students. The focus of the problem in this research is how to apply the prophetic method to SDTI Sekolah Unggulan Islami (SUIS), a descriptive qualitative research method. While the methods used to collect data are through observation, interviews, and documentation. To analyze the data, the researcher used a qualitative descriptive analysis technique, which describes the data that has been collected to describe reality in accordance with the actual phenomenon. In conducting interviews, the researcher determined the research subjects, including the principal, curriculum assistant, and thematic subject teachers, in this case the homeroom teacher of class II Elementary School (SD). The result of this research is that the implementation of the prophetic method in SDIT Islamic Superior School has been implemented by the teacher. The teacher has used the prophetic method as a method of delivering lessons according to conditions in the field. The conclusion using the prophetic method by adjusting to the theme of the lesson in thematic books, can be a solution, so that students avoid damaged understanding, all of this can be easily done when the teacher has strong religious knowledge and the correct Islamic World Veiw.
\end{abstract}

\begin{abstract}
ABSTRAK
Kesadaran guru pendidikan bidang studi umum yang mengajarkan pelajaran umum "tematik" hanya sekedar transfer ilmu pengetahuan saja, tampa memikirkan bagaimana cara meningkatkan keimanan dan juga menjaga fitrah peserta didik dari materi ajar yang dapat merusak fitrah peserta didik. Fokus masalah dalam penelitian ini adalah bagaimana penerapan metode profetik pada SDTI Sekolah Unggulan Islami (SUIS), metode penelitian kualitatif deskriptif. Sedangkan metode yang digunakan untuk mengumpulkan data adalah melalui observasi, wawancara, dan dokumnetasi. Untuk menganalisis data, peneliti menggunakan teknik analisis deskriptif kualitatif, yaitu mendeskripsikan data-data yang telah dikumpulkan untuk menggambarkan realitas sesuai dengan fenomena yang sebenarnya. Dalam melakukan wawancara peneliti menentukan subjek penelitian antara lain kepala sekolah, waka kurikulum, dan guru pengampuh pelajaran tematik dalam hal ini wali Kelas II. Hasil penelitian ini adalah implementasi motede profetik di SDIT Sekolah Unggulan Islami secara pelaksananaa telah diterapkan oleh guru. guru telah menggunakan metode profetik sebagai metode dalam menyampaikan pelajaran dengan menyesuiakan keadaan dilapangan. Adapun kesimpulan menggunakan metode profetik dengan menyesuikan tema pelajaran, dapat menjadi solusi, agar
\end{abstract}


peserta didik terhindar dari pemahaman yang rusak, semua itu dapat dengan mudah dilakukan ketika guru memiliki ilmu agama yang kuat dan Islamic World Veiw yang benar.

Keywords: implementasi, metode profetik, pelajaran tematik

\section{PENDAHULUAN}

Pendidikan menjadi hal yang sangat penting dalam kehidupan manusia, selain bertujuan untuk mengembangkan potensi manusia juga diharapkan mampu menjaga keimanan dan ketakwaan manusia kepada Allah S.W.T. Hal ini sangat selaras dengan tujuan pendidikan nasional. Sebagaimana yang tertuang dalam tujuan pendidikan nasional adalah pengembangan kemampuan dan pembentukan watak serta peradaban bangsa yang bermartabat dalam rangka mencerdaskan kehidupan bangsa, bertujuan untuk mengembangkan potensi peserta didik agar menjadi manusia yang beriman dan bertakwa kepada Tuhan Yang Maha Esa, berakhlak mulia, sehat, berilmu, cakap, kreatif, mandiri, dan menjadi warga negara yang demokratis serta bertanggung jawab (Undang-Undang No. 20, Tahun 2003. Pasal 3).

Pendidikan di Indonesia saat ini, masih mengadopsi dari sistem pendidikan Barat yang bersifat sekuler, pluralisme, dan materialistik yang berorientasikan kepada materi semata dan dalam implementasinya pun terjadi pemisahan satu dengan yang lainnya dalam artian masih menerapkan sistem dualisme (Makmun, 2003). Meskipun pendidikan yang dilaksanakan di Barat membawa kemajuan yang sangat signifikan, semestinya hal itu tidak dijadikan sebagai model utama (role model) atau pun dijadikan landasan dan pijakan dalam melaksanakan pendidikan Islam dalam rangka memajukan peradaban Islam yang damai dan ramah terhadap kehidupan manusia.

Penerapan sistem pendidikan yang demikian menimbulkan dualisme dalam rangka pendidikan di Indonesia. Dipihak tertentu, pendidikan dan pengajaran ilmu pengetahuan umum menitik beratkan pada pengembangan rasionalisasi, sedangkan pendidikan dan pengajaran agama lebih mengutamakan pembinaan moral, etik, dan spiritual. Ini menimbulkan kesenjangan dalam kehidupan sosial kemasyarakatan (Hasbullah, 1999).

Pembelajaran tematik merupakan pendekatan belajar mengajar yang melibatkan beberapa bidang studi. Pendekatan belajar mengajar seperti ini diharapkan akan dapat memberikan pengalaman yang bermakna kepada anak peserta didik. Arti bermakna disini dikarenakan dalam pembelajaran terpadu diharapkan peserta didik akan memperoleh pemahaman terhadap 
konsep-konsep yang mereka pelajari melalui pengalaman langsung dan menghubungkannya dengan konsep lain yang sudah mereka pahami (Suwanto, 2008).

Sistem pembelajaran tematik adalah proses pembelajaran dengan menggunakan pendekatan pemahaman objektif pengetahuan umum dengan pengetahuan agama Islam. Kebijakan ini sering disebut pembelajaran dengan pendekatan IMTAK dan IPTEK. Dengan demikian guru bidang studi umum dituntut memiliki kemampuan yang baik dalam menjelaskan suatu objek atau pegetahuan umum sekaligus dapat mengkorelasikan dengan kebenaran firman Allah S.W.T. dalam Al-Qur'ān dan hadits. Pendekatan ini bertujuan agar peserta didik memiliki pemahaman nondikotomik keilmuan, yakni kesatuan ilmu antara pengetahuan umum dengan pengetahuan agama Islam (Ahmad Tafsir, 2002).

Dari beberapa kelebihan yang didapatkan dari sistem pembelajaran tematik ini, terdapat masalah besar yang harus diperhatikan oleh guru bidang studi umum, sebagai pengajar dan siswa sebagai pembelajar yaitu materi-materi pembelajaran yang dapat merusak pemahaman akidah peserta didik. Menurut Adian Husaini, pengajaran toleransi dalam buku teks PPKn juga telah mengajarkan hal-hal yang diharamkan. Misalnya ditemukan buku PPKn untuk SD/MI Kelas I ditemukan dialog, "Meri, hari Minggu kita main boneka yuk!". Dijawab oleh temannya, "Aku tidak bisa, aku harus ke Gereja". Dalam buku halaman 14 itu, siswa diberi dua opsi jawaban untuk memilih. Pertama, "Kamu tidak usah ke gereja!” dan kedua, "Selamat beribadah Meri!'” Dari latihan tersebut siswa digiring untuk memilih jawaban kedua. Padahal jawaban kedua merupakan ucapan selamat ibadah kepada non-muslim, dimana kaum muslimin diharamkan mengucapkannya (Kholili Hasib, 2014).

Metode profetik merupakan proses untuk memanusiakan manusia, yaitu proses pemanusiaan dan kemanusiaan (Sudarwan Danim, 2006). Proses pemanusiaan adalah pendidikan yang orientasinya untuk menjadikan manusia bernilai secara kemanusiaan, membentuk manusia sejati, memiliki dan mempertahankan nilai etika dan moral, dan memiliki semangat spiritual. Proses kemanusiaan adalah pendidikan yang orientasinya untuk mengangkat harkat martabat manusia melalui penguasaan Ilmu Pengetahuan dan Teknologi (IPTEK), serta memiliki keterampilan profesional (Muhammad Athiyah, 1969).

Kuntowijoyo membagi tiga pilar utama dalam nalar profetik yaitu, al-amr bi al-ma'rûf (humanisasi) mengandung pengertian memanusiakan manusia, al-nahy 'an al-munkar (liberasi) mengandung pengertian pembebasan dan tu'minûna bi Allâh (transendensi), 
dimensi keimanan manusia. Maka di dalam pendidikan profetik, pendidikan tidak hanya dilakukan untuk mengejar standar kompetensi dan tujuan di dalam kurikulum saja. Peserta didik dalam setiap sesi mata pelajaran harus diajak berdialog, berdiskusi dan mengkontekstualkan apa yang sedang dibahas dalam mata pelajaran tersebut dengan realitas sosial yang sedang terjadi (Zainuddin, 2014).

Melihat keberhasilan Nabi Muhammad S.A.W. sebagai seorang pendidik dan pengajar yang sukses, mampu mengeluarkan manusia dari pemahaman jahiliyah menuju manusia yang hanya meyakini Allah S.W.T. sebagai tuhan yang berhak diibadahi dan dimintai bantuan, seharusnya umat Islam dapat menjadikan Nabi Muhammad S.A.W. sebagai contoh dalam membangun kualitas pendidikan. Sehingga dengan berpedoman pada ajaran Nabi Muhammad S.A.W. yang telah terbukti hasil gemilangnya dalam kancah pendidikan, diharapkan dapat melahirkan sebuah generasi yang berilmu, berintelektual dan berakhlak, dan bermoral Islami.

Penelitian ini dilakukan di SDIT Sekolah Unggulan Islami (SUIS) Bogor tepatnya di kampung cimangglid desa sukamantri, kabupaten bogor selatan, pemilihan lokasi ini, karena SDIT SUIS merupakan sekolah berbasis Islam terpadu, dan telah dianggap suskse dalam memadukan antara kurikulum dinas dan juga diniyyah sebagai kurikulum yang digunakan di sekolah. Selain itu juga dalam pengelolaan pembelajaran telah di tata dengan sedemikian moderen sehingga mengikuti perkembangan zaman. Sehingga sekolah ini sangat layak dijadikan acuan dalam metode pembelajaran. Penelitian tentang implementasi metode profetik di SDIT SUIS ini sangat penting dilakukan sebagai upaya untuk mencari tahu metode yang pas digunakan saat pembelajaran tematik di Sekolah Dasar (SD) secara umum.

\section{TINJAUAN PUSTAKA}

Metode dalam Bahasa Arab, dikenal dengan istilah thariqah yang meliki arti langkahlangkah strategis yang dipersiapkan untuk melakukan suatu pekerjaan (Ramayulis, 2013). Apabila dihubungkan dengan pendidikan, maka metode itu harus diwujudkan dalam proses pendidikan, dalam rangka mengembangkan sikap mental dan kepribadian agar peserta didik menerima pelajaran dengan mudah, menyenangkan, dan efektif, serta dapat dicerna dengan baik oleh peserta didik.

Adapun secara istilah, para ahli mendefinisikan metode sebagai berikut; Anung AlHamat, mendefinisikan metode adalah cara yang dilakukan oleh pendidik dalam proses belajar 
mengajar dengan memperhatika situasi dan kondisi, dan pada setiap tempat dapat menggunakan metode yang berbeda-beda sesuai kondisi yang dihadapi, oleh sebab itu penting bagi seorang pengajar memilih metode dengan cermat, disesuaikan dengan berbagai faktor terkait, sehingga hasil pendidikan dapat memuaskan (Anung, 2016). Kemudian Sholih Ali Abu Arrad, mendefinisikan bahwa metode adalah tata cara yang melalui sarana perwujudan interaksi yang baik dan positif antara poros proses pendidikan, dan penggunaannya secara positif untuk mewujudkan tujuan-tujuan yang dicanangkan (Sholih, 2015).

Abuddin Nata, mendefinisikan bahwa metode adalah cara atau langkah-langkah sistematik yang ditempuh oleh seorang guru dalam menyampaikan materi pelajaran kepada peserta didik (Abuddin, 2016) .

Metode mengajar merupakan cara-cara yang digunakan guru untuk menyampaikan bahan pelajaran kepada siswa untuk mencapai tujuan. Dalam proses mengajar, makin tepat metode yang digunakan guru maka akan makin efektif proses belajar mengajar yang dilaksanakan yang selanjutnya akan menunjang dan mengantarkan keberhasilan belajar siswa dan keberhasilan mengajar yang dilakukan oleh guru. Sebaik apapun tujuan pendidikan, jika tidak didukung oleh metode yang tepat, maka tujuan pendidikan tersebut sangat sulit untuk dapat tercapai dengan baik (Ratna, 2019). Tidaklah berlebihan jika ada sebuah ungkapan “aththariqah ahammu minal maddah", bahwa metode jauh lebih penting dibanding materi, karena sebaik apapun tujuan pendidikan, jika tidak didukung oleh metode yang tepat, tujuan tersebut sangat sulit untuk dapat tercapai dengan baik. Sebuah metode akan mempengaruhi sampai tidaknya suatu informasi secara lengkap atau tidak (Qomari, 2003).

Berdasarkan beberapa definisi dan penjelasan tersebut di atas dapat disimpulkan bahwa metode adalah langkah-langkah yang digunakan oleh pendidik guna tersampainya pelajaran kepada peserta didik sesuai dengan apa yang telah direncanakan atau tujuan yang hendak ingin dicapai setalah proses belajar mengajar.

Kata profetik berasal dari bahasa Inggris yaitu "prophetic” yang berarti Nabi. Profetik juga berarti kenabian atau sifat yang ada dalam diri Nabi Muhammad ', yaitu sebagai insan yang ideal secara individual, spritual, dan juga sebagai pelopor perubahan, dengan cara membimbing dan mengajak manusia untuk melakukan perbuatan baik dan berjuang untuk membasmi penindasan di muka bumi. Metode pendidikan profetik mengandung arti metode atau cara Islam yang menggunakan misi kenabian sebagai basis pengembangannya. Misi 
metode pendidikan profetik adalah memperbaiki akhlak dan perilaku umat, sebagaimana dengan tujuan di utusnya Nabi Muhammad S.A.W., beliau diutus di muka bumi ini untuk menjaga dan memelihara fitrah (kesucian) akidah (John, 2006).

Misi pendidikan profetik tidak terlepas dari misi utama diutusnya Nabi Muhammad S.A.W. itu untuk meperbaiki perilaku manusia, membentuk manusia agar memiliki keseimbangan sinergis antara jasmaniah dan rohaniayah. Sedangkan misi sentral kependidikan Nabi Muhammad S.A.W. adalah menanamkan akidah tauhid yang benar, merawatnya dari berbagai macam perusak tauhid yang murni, mendidik manusia untuk memahami seluruh fenomena alam dan kemanusiaan secara holistic (keseluruhan) (Kamisi, 2013) membentuk manusia yang memiliki kualitas yang seimbang antara iman, ilmu dan amal, cakap lahiriah (nampak) maupun batiniah (tidak nampak), kualitas yang seimbang antara emosianal, rasional, dan spiritual, menegakkan masyarakat yang adil, sehat harmonis, sejahtera secara material dan spiritual, dan mengembangkan kualitas kehidupan manusia, menyucikan moral membekali manusia modal yang diperlukan untuk hidup bahagia di dunia dan bahagia di akhirat.

Pendidikan profetik sejatinya merupakan proses untuk memanusiakan manusia, dalam konteks ini ada dua agenda penting yakni proses pemanusiaan dan proses kemanusiaan. Proses pemanusiaan adalah sebuah agenda pendidikan untuk menjadikan manusia bernilai secara kemanusiaan, membentuk manusia menjadi insan sejati, memilki dan menjunjung tinggi tata nilai etik dan moral, memiliki semangat spiritualitas. Proses kemanusiaan adalah sebuah agenda pendidikan untuk mengangkat martabat manusia melalui penguasaan ilmu pengetahuan dan teknologi, serta keterampilan profesionali yang dapat meningkatkan harkat dan martabatnya sebagai manusia (Zainuddin, 2018).

Jadi dapat disimpulkan bahwa metode profetik adalah suatu upaya atau cara yang dilakukan oleh Nabi Muhammad S.A.W. dalam mendidik para sahabatnya, agar memahami, dan mengamalkan ajaran Islam. Sehingga selamat di dunia dan juga di akhirat.

Pembelajaran tematik adalah salah satu strategi pembelajaran terpadu yang menggunakan tema untuk mengaitkan beberapa tema pelajaran satu dengan lainnya sehingga dapat memberikan pengalaman bermakna pada siswa. Rancangan pembelajaran tematik juga salah satu penambahan pada pola pikir dua tokoh tentang pendidikan yaitu, Jacob pada rancangan materi ajar interdisipliner serta Fogety pada rancangan materi ajar terpadu (Retno, 2012). 
Tema menjadi pokok pembicaraan atau gagasan yang mudah memusatkan siswa pada satu tema tertentu. Dengan strategis pembelajaran tematik ini, siswa akan lebih fokus dan konsentrasi sehingga pemahaman terhadap suatu materi pelajaran akan lebih mendalam. Pembelajaran tematik lebih menekankan pada keterlibatan siswa secara aktif. Siswa tidak hanya dijadikan sebagai objek, tetapi siswa dituntut aktif untuk terlibat langsung di lapangan. Keterlibatan aktif akan membuat siswa memperoleh pengalaman yang luas. Pengalaman inilah yang akan membawa siswa mampu menghubungkan antara satu konsep dengan konsep yang lain (Budi, 2013).

Pembelajaran tematik dikemas dalam satu tema atau disebut dengan istilah tematik. Pendekatan ini merupakan satu usaha untuk mengintegrasikan pengetahuan, kemahiran dan nilai pembelajaran serta pemikiran yang kreatif dengan menggunakan tema. Dengan kata lain pembelajaran tematik adalah pembelajaran yang menggunakan tema dalam mengaitkan beberapa mata pelajaran sehingga dapat memberikan pengalaman bermakna bagi peserta didik (Yunanto, 2004).

Dikatakan bermakna karena dalam pembelajaran tematik, peserta didik akan memahami konsep-konsep yang mereka pelajari melalui pengalaman langsung dan menghubungkan dengan konsep-konsep yang dipelajari dengan konsep lain yang telah dipahaminya. Pendekatan ini berangkat dari teori pembelajaran yang menolak proses latihan/hafalan (drill) sebagai dasar pembentukan pengetahuan dan struktur intelektual anak (Zakiah, 2008).

Dalam pembelajaran tematik mencakup beberpa landasan yang diantaranya adalah, landasan filosofis, landasan psikologis, lnadasan yuridis. Adapun prinsip pembelajaran tematik adalah prinsip penggalian tema, prinsip evaluasi, prinsip rekreasi. Pembelajaran tematik memilki krateristik diantaranya adalah berpusat pada peserta didik, memberikan pengalaman langsung, pemisahan mata pelajaran tidak begitu jelas, menyajikan konsep dari berbagai mata pelajaran, bersifat fleksibel, hasil pembejalaran sesuai dengan minat dan kebutuhan peserta didik, menggunakan prinsip belajar sambil bermain dan menyenangkan. Tahap-tahap pembejalan tematik; tahap perencanaan pembelajaran tematik, tahap pelaksanaan pembelajaran, tahap penilaian pembelajaran tematik 


\section{METODE}

Metode yang digunakan dalam penelitian ini adalah metode kualitatif dengan metode analisis deskriptif. Adapun sumber data primer dalam penelitian ini Dan teknik pengumpulan data melalui observasi dan wawancara. Sumber utama penelitian ini adalah Kepala Sekolah, Waka Kurikulum, Wali Kelas II. Sebagai sumber data untuk memperoleh data yang komprehensif penelitian melakukan observasi untuk memperolehh dokumen profil sekolah beserta visi dan misi, data siswa, data karyawan, struktur organisasi, dokumen-dokumen tersebut digunakan untuk melengkapi data penelitian sehingga dapat ditampilkan gambaran tentang objek penelitian secara komprehensif. Dari data itu semua peneliti akan menjabarkan apa yang dimaksud dengan metode profetik dalam buku Abdul Fattah Abu Ghuddah, Implementasi metode profetik di SDIT Sekolah Unggulan Islami (SUIS) Bogor.

\section{PEMBAHASAN}

\section{Pembelajaran Tematik Terpadu untuk Kelas II Sekolah Dasar (SD)}

Buku tematik merupakan buku panduan sekaligus buku aktivitas yang akan memudahkan para siswa untuk terlibat aktif dalam pembelajaran. Dalam buku tematik, didesain penuh gambar dan warna untuk menstimulus imajinasi dan minat siswa. Di dalamnya delengkapi dengan penjelasan lebih rinci tentang isi dan cara penggunaan sebagaimana yang dituangkan dalam buku panduan guru. Kegiatan pembelajaran yang ada di dalam buku tematik lebih merupakan contoh kegiatan yang dapat dipilih oleh guru dalam melaksanakan pembelajaran. Guru diharapkan dapat mengembangkan ide-ide kreatif lebih lanjut dengan memanfaatkan alternatif-alternatif kegiatan yang ditawarkan di dalam buku panduan guru, atau mengembangkan ide-ide pembelajaran sendiri.

Pembelajaran tematik pada sekolah dasar Kelas II menghimpun mata pelajaran yaitu; PPkn, Bahasa Indonesia, Matematika, SBdP, dan PJOK dan telah dibagi kedalam 8 tema. Adapun sub-sub pembahasan dari tema tersebut adalah, Tema 1 membahas tentang hidup rukun, tema 2 membahasa tentang bermain di lingkunganku, tema 3 membahas tentang tugasku sehari-hari, tema 4 membahas tentang hidup bersih dan sehat, tema 5 membahas tentang pengalamanku, tema 6 membahas tentang merawat hewan dan tumbuhan, tema 7 membahas tentang kebersamaan, tema 8 membahas tentang keselamatan di rumah dan di perjalanan. 
Setiap tema terdiri dari 4 subtema, tiap subtema diuraikan ke dalam 6 pembelajaran.satu pembelajaran dialokasikan untuk 1 hari. Penjelaskan lebih rinci dituangkan di dalam buku panduan guru. Struktur penulisan buku semaksimal mungkin diusahakan memfasilitasi pengalaman belajar yang bermakna yang diterjemahkan melalui subjudul seperti; ayo mengamati, ayo bermain peran, ayo berlatih, ayo bercerita, ayo berkreasi, ayo menulis, ayo membaca, ayo bernyayi, ayo berkreativitas, ayo berdiskusi, ayo menanya, dan kegiatan bersama orang tua.

Buku tematik ini bersifat serba mencakup (self contained) agar dapat digunakan oleh orang tua di rumah secara mandiri untuk mendukung aktivitas belajar siswa di rumah. Disetiap akhir pembelajaran, terdapat kolom untuk orang tua dengan subjudul kegiatan bersama orang tua, kolom ini berisi aktivitas belajar yang dapat dilakukan oleh orang tua bersama siswa. Orang tua diharapkan berdiskusi dan terlibat aktif dalam aktivitas belajar siswa. Pada setiap akhir subtema terdapat lembar refleksi dari ikon "Sekarang Aku Bisa", lembaran ini bertujuan membantu siswa dan guru mengetahui apa yang telah dicapai dan apa yang harus ditingkatkan, kemudian pada lembaran paling akhir pada setiap subtema terdapat lembar penialaian yang dapat digunakan sebagai alat penilaian pencapaian kompetensi. Guru juga bisa mengembangkan alat penilaian sendiri sesuai dengan kebutuhan di lapangan.

\section{Landasan filosofis}

Pengunaan metode dalam proses belalajar mengajar pada SDIT Sekolah Unggulan Islami (SUIS) Bogor berlandaskan pada wahyu Allah S.W.T. yaitu pada Al-Qur'an dan As-Sunnah. Sehingga dalam penerapan metode pembelajaran pada semua pelajaran lebih khusus pelajaran tematik berdasarkan pada landasan tersebut Al-Qur'an dan As-Sunnah.

\section{Implementasi Metode Profetik Pada Pelajaran Tematik}

Dari segi prakteknya, SDIT Sekolah Unggulan Islami SUIS Bogor, para guru sudah terbiasa memberikan pelajaran dengan menggunakan metode profetik, walaupun secara khusus tidak mengatasnamakan istilah metode profetik, seperti ketika menyampaikan materi pada kegiatan spiritual morning di pagi hari atau ketika selesai shalat dhuha guru memberikan pelajaran dengan kisah orang shaleh, Tanya jawab, memberikan pelajaran tanpa ditanya, menyuruh siswa untuk mengulang apa yang telah disampaikan oleh guru di depan temantemannya. 
Jadi, secara penerapan guru-guru telah menerapkan metode profetik dalam kegiatan belajar mengajar, dengan merujuk pada visi, misi, dan tujuan yayasan juga sekolah. Dan itu terlihat dari semua kegiatan yang berlasung di dalam kelas maupun di luar kelas seperti pada kegiatan halaqah tahfidz, halaqah tahsin, kegiatan pramuka, belajar bahasa arab, belajar bahasa inggris, belajar aqidah, belajar fiqih, belajar pelajaran agama Islam, dan juga tematik. Dalam pelajaran tematik khususnya sedikit banyaknya telah menggunakan metode profetik dalam kegiatan belajar mengajar.

Adapun metode profetik yang biasa digunaka pada pembelajaran tematik pada SDIT Sekolah Unggulan Islami (SUIS) Bogor berikut;

a. Metode bertanya

Metode bertanya merupakan suatu upaya yang dilakukan oleh guru untuk menggali sejauh mana pengetahuan siswa terhadap materi yang sudah dipelajari atau yang akan dibahas, yang disajikan dalam bentuk percakapan (tanya jawab) antara guru dengan siswa, siswa dengan guru, atau siswa dengan siswa bersdasarkan argument-argumen yang bisa dipertanggungjawabkan secara ilmiah (Sani, 2016). Rasululah ` sering menjadikan metode tanya jawab sebagai wasilah dalam menyampaikan pelajaran kepada para sahabatnya, belaiu lakukan hal tersebut untuk mengarahkan perhatian para sahabat, memancing antusiasme mereka supaya mencari jawaban, dan mendorong mereka mendaya gunakan pikiran untuk menjawab pertanyaan yang dilontarkan beliau (Abdul Fattah, 2018).

Oleh sebaba itu, bagi guru pengampuh pelajaran tematik lebih khususnya dan bagi siapa saja yang berprofesi sebagai guru pengajar, metode tanya jawab bisa menjadi solusi untuk mengetahui kadar pemahaman siswa terhadap materi dalam sub-sub tema yang akan diajarkan, Atau memberikan pertanyaan sebagai cara untuk menfokuskan perhatian siswa ketika hendak pelajaran dimulai. Selain memiliki kelebihan, metode Tanya jawab juga terdapat beberapa kekurangan, diantaranya, waktu banyak terbuang. Jadi ketika guru menggunakan metode tanya jawab, jangan bertanya terhadap sesuatu yang tidak ada hubungan langsung dengan materi yang sedang dipelajari.

b. Metode kisah

Metode kisah merupakan metode yang biasa Rasulullah ', karena metode kisah dianggap lebih mampu memberikan kesan yang baik, lebih menarik perhatian, lebih 
mendorong mereka untuk mencurahkan semua tenaga dan perhatian, serta lebih merasuk kedalam hati dan telinga mereka secara maksimal. Selain itu metode kisah juga memperkuat pemahaman peserta didik akan pelajaran yang sudah dipelajari, hal ini sebagaimana firman Allah I dalam QS. Huud [11]: 120

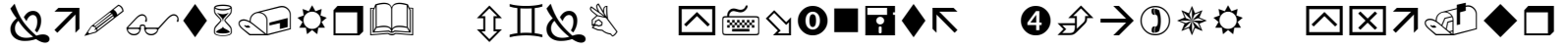

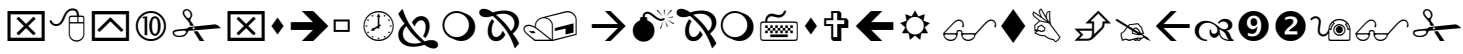
Dan kami ceritakan kepadamu kisah-kisah para rasul (terdahulu) yang dengannya Kami teguhkan hatimu. (Depertemen RI, 2018)

Ayat tersebut menjadi dalil bahwa mengajar dengan menggunakan metode kisah dapat memperkokoh pengetahuan dan keyakinan siswa terhadap materi yang telah dipelajari, namun disisi lain masih terdapat kelemahan, karena setiap metode tidak ada yang sempurna, disana pasti terdapat kelebihan dan juga kekurangan.

c. Metode Memperlihatkan Sesuatu yang Dilarang untuk Menekankan Keharamannya Untuk menjelaskan bahwa sesuatu benda itu dilarang (diharamkan) Rasulullah `acap kali menggunakan metode alat peraga. Beliau memperlihatkan sesuatu yang dilarang itu dan mengangkatnya tinggi-tinggi dengan tangannya di hadapan orang yang sedang belajar sama beliau (Abdul Fattah, 2018).

Dalam pembelajaran tematik, guru bisa menggunakan metode ini, dengan menggunakan peraga sebagai perantara untuk menyampaikan materi pelajaran yang dimaksud, karena dalam pembelajaran tematik guru tidak dibatasi dalam memilih dan menggunakan cara, selama cara itu bisa menyampaikan pelajaran yang dimaksud kepada peserta didik. Metode ini juga bisa menjadi solusi bagi guru dalam menfilter materi-materi yang membahayakan aqidah dan keyakinan siswa.

Dengan adanya kebebasan dalam mengreasikan bentuk penyampaian belajaran menjadi kesempatan emas bagi guru untuk melakukan berbagai cara agar peserta didik pahama dengan apa yang disampaikan.

d. Metode Keteladanan dan Akhlak Mulia

Metode keteladanan dan juga akhlak mulia merupakan metode inti dari proses belajar mengajar, guru harus bisa menjadi contoh bagi siswa sebagaimana dalam sebuah ungkapan guru itu digugu dan ditiru, karena sebaik apapun materi atau pelajaran yang kita sampaikan dalam proses belajar di dalam kelas, ketika tidak ada keteladanan dan 
juga akhlak dari guru, maka itu akan menjadi nol besar, karena akan kecil cenderung mencontoh apa yang dilakukan oleh guru, bukan apa yang diajarkan oleh guru di kelas. Oleh sebab itu, ketik guru menyampaikan materi terkait menjaga lingkungan, guru harus lebih dahulu menjaga lingkungan sekolah dengan tidak membuang sampah atau memungut sampah yang serakan ketika melihat sampah. Dengan contoh seperti itu, siswa akan langsung paham apa yang dimaksud dengan menjaga lingkungan dan juga kebersihan.

e. Metode Mengajar dengan Kepribadian yang Luhur

Memiliki kepribadian yang luhur adalah sesuatu keharusan bagi seorang guru, Rasulullah telah memberikan contoh kepada kita bagaimana menjadi seorang guru yang memiliki kepribadian yang luhur dan Allah I telah memuji bagaimana kesempurnaan kepribadian Rasulullah `.

Oleh sebab itu, menurut peneliti menjadi seorang guru tidak cukup pandai dalam menyampaikan materi pelajaran, akan tetapi sebagai seorang guru harus berpenampilan rapi, bersih, menarik, bijaksana, tindakan yang baik dan menjaga ucapan. Hal itu bisa diaplikasikan ketika mengajar, guru berpakaian rapi, menggunakan pakain yang layak, ucapan yang baik-baik. Karena siswa akan melihat dan mengamalkan apa yang ia lihat dari tindak-tanduk gurunya.

f. Metode reward and panishment

Memberikan hadiah dalam proses belajar mengajar merupakan metode yang sangat sederhana, tapi memiliki dampak yang sangat besar dalam meningkatkan motivasi siswa mengikut pelajaran, Menurut Ngalim Purwonto, pemberian hadiah adalah salah satu alat untuk mendidik peserta didik agar senang terhapat perbuatan ata pekerjaannya (Ngalim, 2011). Adapun metode hukuman adalah bertujuan untuk memperbaik perilaku buruk peserta didik, dan itu dilakukan dengan penuh kehati-hatian. Menurut Abu Ahmadi dan Nur Uhbiyati pemberian hukuman adalah penderitaan yang diberikan dengan sengaja oleh pendidik setelah peserta didik melakukan kesalahan dan pelanggaran (Abu Ahmadi, 2001).

\section{Evaluasi Metode}

Dalam dunia pendidikan kegiatan evaluasi menjadi hal yang wajib ada sebagai sarana untuk mengukur seberapa sukses daya serap siswa terhadap materi pelajaran yang 
disampaikan oleh guru di kelas, juga untuk mengukur sejauh mana metode yang digunakan mampu memberika pengaruh yang segnifikan dalam menjebatani proses transfer ilmu pengetahuan dari pendidik ke pada peserta didik. Oleh sebab itu untuk mengetahui berhasil atau tidaknya penerapan metode profetik dapat dilihat dari beberapa faktor diantaranya adalah:

1. Perilaku Peserta Didik

Ciri khas SDIT Sekolah Unggulan Islami (SUIS) sebagaimana yang tergambar pada visi dan misi sekolah yaitu menjadi peserta didik yang mempunyai "akidah yang hanif, dan berakhlak mulia" dalam mengimplementasikan visi dan misi tersebut SDIT Sekolah Unggulan Islami (SUIS) menjalankan beberapa kegiatan seperti memberikan materi dan juga praktik pembiasaan setiap pagi hari di depan kelas, dan juga kegiatan yang lainya. Jika terdapat siswa yang berkata kotor, suka menggangu teman, makan berdiri dan lain sebagainya maka teman yang lain akan mengingatkan atau melaporkan ke guru. Juga sekolah membuat jadwal piket guru pada jam istirahat untuk memantau kegiatan siswa diluar kelas.

2. Secara Akademik

Untuk mengetahui sejauh mana peserta didik menguasai pelajaran yang diajarkan maka SDIT Sekolah Unggulan Islami mengadakan tes evaluasi dalam bentuk ulangan harian, ujian mit semester, atau penlaian akhir semester (PAT)

\section{Secara Sosial}

Sebagai sekolah yang menggunakan sistem full Day, peserta didik akan bergaul dengan masyarakat luas, sehigga peserta didik tidak bisa lepas dari hidup sosial dengan masyarakat, untuk mengukur keberhasilan pendidkan disekolah. SDIT Sekolah Unggulan Islami bekerja sama dengan orang tua untuk memantau perilaku peserta didik.

\section{KESIMPULAN}

Berdasarkan hasil penelitian terkait implementasi metode profetik pada pelajaran tematik di Kelas II SDIT Sekolah Unggulan Islami (SUIS) Bogor maka dapat ditarik kesimpulan sebagai berikut: 
1. SDIT Sekolah Unggulan Islami (SUIS) Bogor dalam hal ini kepala sekolah telah memberikan pengarahan dengan baik terkai metode yang digunakan dalam pembelajaran sehingga para pendidik mampu mengalikasikannya dalam kegiatan belajar mengajar.

2. Keberhasilan dalam mengimplementasikan metode profetik dalam kegiatan belajar mengajar dapat dilihat dengan nilai akademik peserta didik dari waktu ke waktu semakin membaik, perilaku peserta didik semakin hari semakin baik, tidak ditemukan lagi siswa yang mengejek teman, membuli dan lain sebagainya, juga kegiatan muamalah peserta didik dengan masyarakat.

3. Evaluasi terkait implementasi metode menjadi tolak ukur keberhasilan sekolah dalam meningkatkan kulitas peserta didik pada semuai lini (akademik, akhlak, sosial).

\section{DAFTAR PUSTAKA}

Agama RI, Depertemen. (2018). Al-Qur'an dan Terjemahannya. Depok: Penerbit Cahaya Qur'an Tajwid.

Sani, Ridwan, et.al. (2016). Pendidikan Karakter, Mebangun Karater yang Islami. Jakarta: Bumi aksara.

Daradjat, Zakiah. (2008). Pengajaran Agama Islam. Jakarta: Bumi Aksara, 2008

Jabaran UUD. (1945). tentang pendidikan dituangkan dalam Undang-Undang No. 20, Tahun 2003. Pasal 3.

Makmun. (2003). Model pembelajaran menciptakan proses Belajar mengajar Yang Kreatif dan Efektif. Jakarta: Rienika Cipta.

Syarif, Zainuddin. (2014). Pendidikan Profetik Dalam Membentuk Bangsa Religius. Jurnal, Tadris, 9(1).

Hasbullah. (1999). Kapita Selekta Pendidikan Islam. Jakarta: PT RajaGrafindo Persada.

Suwanto, Wiji. (2008). Dasar dasar ilmu Pendidikan. Jogjakarta: Ar-Ruzz Media Group.

Danim, Sudarwan. (2006). Agenda Pembaruan Sistem Pendidikan. Yogyakarta: Pustaka Pelajar.

Purwanto, Ngalim. (2011). Ilmu Pendidikan Teoritis dan Praktis. Bandung: Remaja Rosda Karya.

Nur Uhbiyati dan Abu Ahmadi. (2001). Ilmu Pendidikan. Jakarta: Rineka Cipta.

Hassan Shadily dan John M. Echols. (2006). Kamus Inggris Indonesia. Jakarta: PT. Gramdia Pustaka Utama.

Ramayulis. (2013). Ilmu Pendidikan Islam. Jakarta: PT. Kalam Mulia.

Al-Hamat, Anung. (2016). Tabiyah Jihadiyah Imam Bukhari; Studi Anlisis Hadits-Hadits Kitab Jihad wa Siyar Shahih Bukhari. Jakarta Timur: Ummul Qura. 
Ali Abu Arrad, Sholih. (2015). Muqoddimah Fi Al-Tarbiyah Al-Islamiyah. Bogor: PT. Marwah Indo Media

Nata, Abuddin. (2016). Ilmu Pendidikan Islam. Jakarta: PT. Kencana.

Samsi Nelwati dan Ratna Kasni Yuniendel. (2019). Meneladani Rasulullah Sebagai Pendidik yang Memudahkan. Jurnal Murobby, 2(1).

Anwar, Qomari. (2003). Pendidikan Sebagai Krakter Bangsa, Jakarta: Uhamka Pres.

Tafsir, Ahmad. (2002). Pendidikan Agama dalam Keluarga. Bandung: Remaja Rosdakarya.

Kamisa. (2013). Kamus Besar Bahasa Indonesia; Edisi Terbaru. Surabaya: PT. Cahaya Agency.

Widyaningrum, Retno. (2012). Model Pembelajaran Tematik di MI/SD. Jurnal Cendekia, 10(1).

Athiyah al-Abrasyi, Muḥammad. (1969). Al-Tarbiyyah Al-Islōmiyah wa Fal̄̄sifatuhō Kairo: Is $\bar{\alpha}$ al-Bōbī al-Halabī.

Hartono, Budi. (2013). Ragam Model Mengajar yang Mudah Diterima Murid. Jogjakarta: PT. Diva Press.

Abu Ghuddah, Abdul Fattah. (2018). Muhammad Sang Rasul; Menyibak Rahasia Cara Mengajar Rasulullah. Jakarta: Penerbit Akses.

https://inpasonline.com/kurikulum-2013-antara-idealisme-dan-problem-sekularisme/, diakses pada jam 17:28, tanggal 02/03/2020 